\title{
Nephrocystins play a crucial role in renal epithelial morphogenesis via the regulation of Wnt/PCP components Dishevelled and Rho GTPases
}

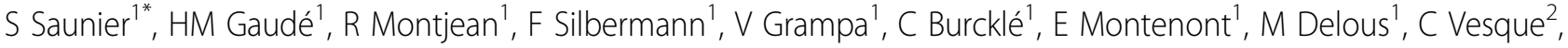 \\ C Jeanpierre ${ }^{1}$, C Antignac $^{1}$, F Terzi $^{3}$, S Schneider-Maunoury ${ }^{2}$
}

From First International Cilia in Development and Disease Scientific Conference (2012)

London, UK. 16-18 May 2012

Nephronophthisis, a hereditary nephropathy characterized by interstitial fibrosis and cyst formation, is caused by mutations in NPHP genes encoding the ciliary proteins called nephrocystins. We investigate the function of nephrocystin-1, -4 and -8 , in vitro and in vivo in mammalian kidney cells and in zebrafish respectively. Depletion of either NPHP1 (N1-KD), NPHP4 (N4-KD) or NPHP8 (N8-KD) by shRNA-mediated knockdown in MDCK cells led to abnormal ciliogenesis and epithelial morphogenesis defects in 3D culture. Moreover nephrocystin-4 modulates the Wnt pathways during morphogenesis of the zebrafish pronephros and in vitro, via proteasomal degradation of cytoplasmic/membranous dishevelled. In addition, we demonstrate that nephrocystin-8 is required for dishevelled stability at the basal body essential for proper PCP. In either N1-KD or N4-KD cells, we also showed an over activation of Cdc42 and RhoA, downstream targets of dishevelled. This was accompanied by actin cytoskeletal disorganization, enhanced spreading on collagen, overactivation of proteins that regulate focal adhesion structures i.e p130cas-Pyk2 and increased cell migration. Interestingly, the stable expression of dominant negative form of Cdc42 in knockdown cells rescued the migration and the 3D phenotypes. In parallel, we observed that loss of Nphp4 in mice caused cystic tubular dilatation after subtotal nephrectomy correlated with alteration of ciliogenesis and over activation of Cdc42 and RhoA. Our data show a role of nephrocystins in epithelial cell organization and kidney morphogenesis via the regulation of the Wnt/PCP components including dishevelled and the Rho GTPases.

* Correspondence: sophie.saunier@inserm.fr

${ }^{1}$ Hôpital Necker, Inserm U983, France

Full list of author information is available at the end of the article
Author details

${ }^{1}$ Hôpital Necker, Inserm U983, France. ${ }^{2}$ CNRS UMR 7622, INSERM U969, France. ${ }^{3}$ INSERM U845, France.

Published: 16 November 2012

doi:10.1186/2046-2530-1-S1-P100

Cite this article as: Saunier et al: Nephrocystins play a crucial role in renal epithelial morphogenesis via the regulation of Wnt/PCP components Dishevelled and Rho GTPases. Cilia 2012 1(Suppl 1):P100.
Submit your next manuscript to BioMed Central and take full advantage of:

- Convenient online submission

- Thorough peer review

- No space constraints or color figure charges

- Immediate publication on acceptance

- Inclusion in PubMed, CAS, Scopus and Google Scholar

- Research which is freely available for redistribution

Submit your manuscript at www.biomedcentral.com/submit
C Biomed Central
() Biomed Central

ㄷ 2012 Saunier et al; licensee BioMed Central Ltd. This is an Open Access article distributed under the terms of the Creative Commons Attribution License (http://creativecommons.org/licenses/by/2.0), which permits unrestricted use, distribution, and reproduction in any medium, provided the original work is properly cited. 